\title{
4. A (non-)violent revolution? Strategies of civility for the politics of the common
}

\section{Christiaan Boonen*}

\section{INTRODUCTION}

In an attempt to make sense of our current political conjuncture showing both signs of crisis and political invention - many are starting to pay attention to the ascendance of political practices echoing those of the 1871 Paris Commune: the occupation of public spaces, the adoption of direct democratic forms, attempts to organize social life according to principles of association and cooperation, resistance to centralized government and a refusal to renounce an internationalist horizon (Ross, 2015: pp. 1-9). Every now and then, it seems, political actors recover the 'lost treasure' of the revolutionary tradition. These are the new forms of government that emerge during the course of all great revolutions - popular organs that, as a result of the concerted action of citizens, constitute spaces of freedom beyond the purview of the nation state (Arendt, 2016 [1963]: pp. 215-81).

The recent work of Pierre Dardot (Chapter 2 in this volume) and Christian Laval relates to this context. As the subtitle of their latest book Commun: Essai sur la révolution au XXIe siècle reveals, they are engaged in a fundamental reassessment of the theory and practice of revolution (Dardot and Laval, 2014). Yet, they are equally suspicious of the grand schemes typical of nineteenth- and twentieth-century revolutionary thought, which tended to obscure or suppress the actual political and social revolutions taking place in the name of a 'greater' revolution-tocome. Following an incisive analysis of our current predicament that traces the extension of neoliberal reason to the different spheres of human existence, they set upon developing a political answer (Dardot and Laval, 2009). Central to this book entitled La nouvelle raison $d u$ monde is the assertion that the neoliberal project is a 'constructivist project'. ${ }^{2}$ Whereas classical liberalism works under the assumption that the propensity to 
truck and barter is inherent to human nature, neoliberalism recognizes that economic rationality cannot be assumed as a natural given. Consequently, neoliberalism should not be seen as a politics that removes the obstacles to our natural inclination to truck and barter, but as a political project that stimulates market competition through permanent intervention. What Dardot and Laval are looking for, then, is a rival project that can counteract this neoliberal form of rationality. They are in search of an alternative to a rationality that reduces every issue of valuation to the simple question: does it enhance market competition or does it weaken it? This alternative reason they call the reason of the common (Dardot and Laval, 2009: pp. 457-81). To neoliberalism's depoliticization of all spheres of society, they oppose a project for the democratization of all the important spheres of society (work, nature, culture and so on). To an individualist and competitive neoliberal subjectivity, they oppose a form of collectivity and solidarity. And, perhaps most importantly, to neoliberalism's celebration of private property, they oppose a project of making the important spheres of human life non-appropriable. In the end, this is the baseline identified in Commun: what is important to human flourishing should never become a form of property.

It is important to emphasize that this new guiding principle should be political in nature. This means that they position themselves in opposition to two sets of literature. On the one hand, they counter the literature on the enclosure of the commons (for example, David Bollier and James Boyle) and common-pool resources (CPRs) (for example, Elinor Ostrom). On the other, they engage critically with a radical left literature on the common (for example, Michael Hardt and Antonio Negri). As opposed to the first set of literature, they maintain that it is more fruitful to speak of the principle of the common than of commons in the plural. The principle of the common, they argue, is expansive: generally speaking you can make any sphere of society operate according to the principle of the common. In contrast to this view, the literature on the enclosure of commons and CPRs assumes that commons are specific economic entities that either have to be defended against market and state, or live in harmony with market and state. In both cases the implications are potentially conservative: commons have a specific place in the socio-economic sphere and the borders with other economic or social entities should be maintained (Dardot and Laval, 2014: pp. 95-187). Pace their radical leftist colleagues, they do not believe that political change will come forth from a specific social place or will be initiated by an already existing 'universal' class (Dardot et al., 2007). It might be the case that certain evolutions in the make-up of our economies are already realizing the principle of the common. We see it, for instance, in the way that Wikipedia makes encyclopaedic knowledge into a common. 
However, economic tendencies, they argue, do not automatically translate into political projects. Hence, a collective political subject will have to be constructed and this requires political practices and institution-building. To be more precise, 'common acting' (agir commun) produces a collective subject, and not the other way around (Dardot and Laval, 2014: pp. 49-51, 281-2).

This brings us to the issue at hand: the revolutionary change they envisage does not involve a violent conquest of the state. This old revolutionary recipe only ended up reproducing the forms of domination that it was supposed to abolish. In contrast, Dardot and Laval imagine an 'autoinstitution of society' as practices of commoning more or less spontaneously proliferate in spite of and autonomously from the state, which, at some point, is transformed as a consequence of this expansion (Dardot and Laval, 2014: p. 575). ${ }^{3}$ However, this raises the question of what will happen when either state or capital see their authority or interests endangered. As Ramond Geuss argues, revolutions - as opposed to reforms - always imply a form of extra-legality. Sometimes revolutions are merely extraconstitutional or take place in a grey area of the law. But more structural transformations of society are often illegal - in which case they can be non-violent or violent (Geuss, 2006: p. 111).

Either way, every political project envisioning a fundamental transformation of society (even those willing to adopt the principle of non-violence) will at some point have to reflect on the relation between transformational politics and violence. Reflections on violence are a constant presence in Dardot and Laval's Commun, which addresses the violence of primitive accumulation, statist domination and the systemic violence of the capitalist economic system. Nonetheless, a more systematic reflection on the relation between revolutionary politics and violence, we argue, is missing. To be more precise, we do not criticize them for proposing a non-violent revolution, but for not specifying why non-violence, as a revolutionary strategy, is preferable to violent ones.

This chapter will be structured as follows: in the first section (Section 2) we will determine which concept of politics is present in the revolutionary politics of Dardot and Laval and show that they cannot account for the relation between politics and violence. In particular, we will construct a brief genealogy of the concept of political power inherent to the concept of the common. This is done in order to show how this concept of power makes the violence/non-violence dilemma disappear before it can rear its head. In the second section (Section 3) we sketch the dynamics of power and violence that result from a conflict between the state and the politics of the common. We do this in order to show that political violence is a problem that should be accounted for in the commons literature. In the 
final section (Section 4), we explore the role violence can play and, more importantly, should not play in a revolutionary situation.

\section{THREE CONCEPTS OF POLITICS: EMANCIPATION, TRANSFORMATION AND CIVILITY}

In order to grasp Dardot and Laval's concept of revolution we have to determine which concept of politics - or, rather, political change - is implicit in their work. For ages political theorists have been bickering about the 'what' and 'how' of revolutionary political change and often the debate revolves around the question of which concept of politics to prioritize. Do we prioritize the struggle for rights? Or is it rather the recurrent attempt to seize the means of (re)production that moves history forward? Or maybe we should focus less on the ends of politics and more on the ways in which we relate to political means such as violence and coercion?

When we think about radical political change ${ }^{4}$ - Étienne Balibar writes - we cannot get by without at least three distinct concepts of politics: the politics of emancipation, the politics of transformation and the politics of civility (Balibar, 2002: p. 1). It is an open question whether this list is exhaustive, but at any rate one cannot study radical political change without having at least a notion of these three and their reciprocal interactions.

\subsection{The Politics of Emancipation and the Politics of Transformation}

The first concept of politics is that of the politics of emancipation, which is concerned with the expansion of human rights and the building of civic institutions. The idea that all men are 'free and equal in rights' resides at its core: any situation in which restrictions are imposed on liberty or equality (for example, when civil liberties are based on discrimination) is illegitimate (Balibar, 2002: p. 3). Hence, the main task of emancipatory politics is to build civic institutions that guarantee this equal liberty and give an institutional form to the idea that 'all men are born free and equal'. However, as equal liberty is rarely ceded by those in power, conflict remains a decisive factor. That is, it is the "history of . . the real struggle to enjoy rights which have already been declared' or 'the battle against the denial of citizenship' that is the vital heart of the politics of emancipation (p. 6).

The politics of transformation, on the other hand, challenges one core assumption of the politics of emancipation: namely, that politics is a 
wholly autonomous activity. Fundamentally, politics takes place in 'nonpolitical' conditions that (over)determine it or, at the least, limit it. The boundaries separating the sphere of politics from other societal subsystems are, to a certain extent, artificial. This explains why they can always be contested and why the 'non-political' conditions of political institutions are eminently political (p. 11). Accepting that oppression or inequality cannot always be sublated by the state, law or the rights of man, critical theorists such as Marx and Foucault have sought to show how important forms of political change often take place in the social, economic and cultural contextual conditions of politics (Balibar, 2015a: p. 10).

Dardot and Laval position their revolutionary politics on a terrain comprising these two concepts of politics. To be more precise, they present the politics of the common as a form of politics encompassing transformational politics and the politics of emancipation. ${ }^{5}$ The politics of the common, they argue, is 'transversal to instituted separations' (Dardot and Laval, 2014: p. 460). The political logic of democratic self-governance cannot be limited to the field of state politics or even the political sphere at large, but should also be extended to the social and economic sphere. This is why they argue that a revolution cannot be restricted to - yet should include - political institutions (in the form of 'more rights', or a 'greater inclusivity'), but should also transform the conditions in which politics takes place (p. 572). They envisage this revolutionary movement as 'moment of acceleration, intensification and collectivization of [the] instituting praxis [of "common acting"] in certain important areas of society' (p. 575). As more and more areas of social life are made non-appropriable (inappropriable) through practices of commoning, a qualitative change takes place as state and market, public and private property, are finally subordinated to the principle of the common (p. 582).

As a result, they find themselves at odds with political thinkers who narrowly circumscribe the sphere of politics in order to remove all social and economic questions from its domain. The problem with this reasoning, Dardot and Laval argue, is that it assumes that the sphere of the political is a given even though in a lot of cases social questions are political questions (p. 577). The governance of a natural resource, a workplace or a theatre all merit recognition as public affairs (pp. 463-5).

\subsection{The Commons, Power and Violence}

A third way to look at the problem of political change is to pay attention to political means such as force and violence, as opposed to the ends and objects of change. This particular point of view involves asking questions such as: can we force or coerce those not willing to participate in the 
revolution? And: can we use violence in order to initiate the revolution or safeguard some of its achievements? In other words, it involves asking questions about the nature of (political) action, power and their relation to violence. These questions are central to the politics of civility (see infra).

If we consider the politico-theoretical tradition in a schematic way, we can delineate at least two influential positions on the nature of political power and its relation to violence. On the one hand, we have thinkers like Thomas Hobbes and Max Weber, who conceive of power as power-over, that is, the ability of one person or group of persons to make others perform a specific action (whether or not this action is against the interest of the latter). In the words of Max Weber: power is 'the probability that one actor within a social relationship will be in a position to carry out his own will despite resistance, regardless of the basis on which this probability rests' (Weber, 1978: p. 53). Consequently, violence, domination and coercion are treated as modalities of political action. ${ }^{6}$

On the other hand, we have another view, famously defended by Hannah Arendt which involves an understanding of power as power-with. Power comes into being only when people act in concert or when they engage in cooperation (Saar, 2010: pp. 9-12). Here, power is not something that a certain actor 'has' and exercises over others, but exists 'in between' people. In other words, power is relational as opposed to unilateral (Penta, 1996: p. 212). According to this conception of the political, violence appears as the opposite of power and politics. And this applies irrespective of whether violence manifests itself in the form of legitimate or illegitimate domination, structural or subjective violence, revolutionary or counterrevolutionary violence. In short, violence appears as a form of anti-politics (Arendt, 1969; Frazer, 2014: p. 158). ${ }^{7}$

We argue that their quarrels with Arendt's positions notwithstanding, ${ }^{8}$ Dardot and Laval share her understanding of political action in this particular respect. First of all, they emphasize that a commons revolution would not be violent (Dardot and Laval, 2014: p. 575). Furthermore, significant parts of their book, Commun, are dedicated to analyses of the internal workings of the politics of the common, all of which end up stressing their cooperative and deliberative aspects (for example, Dardot and Laval, 2014: pp. 280-83, 445, 578-82). Violence, on the other hand, is something that is done to the commons. They were captured by socialist states and subjected to the structural violence of bureaucracies (pp. 79-85); they were enclosed in violent episodes of primitive accumulation (pp. 120 24); and, increasingly, we are seeing the echoes of these different forms of violence (pp. 98-119), while new forms of dispossession attest to the structural violence that is inherent in the workings of globalized financial markets (pp. 127-31). 
This view, we would add, is not entirely accidental. In the different intellectual origins of their concept of the common, we see a similar understanding of the nature of power. ${ }^{9}$ Take, for instance, the work of Elinor Ostrom. If we look at her writings, it quickly becomes apparent that she is partisan to the notion of 'power-with'. Her research on CPRs, she argues, challenges 'the Hobbesian conclusion that the constitution of order is only possible by creating sovereigns who then must govern by being above subjects, monitoring them, and by imposing sanctions on all who would otherwise not comply' (Ostrom et al., 1992: p. 414). In other words, people can cooperate and keep credible commitments without there being an external enforcer. This means that, in commons, power does not rest in an external institution or a centralized authority with the ability to impose and enforce rules of action (Ostrom, 2000). It exists in between people in a horizontal contract they conclude among themselves and keep alive through communication and their shared action.

Although this brief outline already shows how coercion and violence are unassimilable to Ostrom's concept of power in commons, we do have to acknowledge that political and social revolutions were never one of her concerns. It is important, then, to point out that the same applies to Dardot and Laval's more radical and explicitly anticapitalistic influences - a tradition of theorizing worker's self-management that has its roots in the work of Pierre-Joseph Proudhon and was further developed in the writings of Marcel Mauss (Dardot and Laval, 2014: pp. 367-403). Proudhon is equally critical of the concept of 'power-over'. To be more precise, Proudhon opposes something he calls collective force to political power. In his own words, '[t]he problem consists, then, for the working classes, not in capturing, but in defeating both power and monopoly' (cited in Allen, 1952: p. 5). The concept of political power refers to every form or instrument of domination - the state, police, workplace hierarchies and so on. It can, in other words, be equated with all forms of 'power-over'. On the other hand, Proudhon's own concept of the institution of collective force can, perhaps somewhat confusingly, be seen as a form of 'powerwith'. It is a form of collective, shared power that is immanent to workers' self-organization. Taken together this adds up to a specific concept of revolution: a revolution takes place as these practices of self-organization spread, realizing a form of social justice in more and more parts of society. As this form of 'power-with' is extended, it will prevail over a state that has become useless (Dardot and Laval, 2014: p. 367). Put differently, as practices of workers' self-organization spread, all forms and instruments of domination, having become obsolete, will wither away. This revolution, consequently, takes place without force or violence being exercised (Solari, 2012: p. 229). Proudhon's revolution was to be non-violent: a survey of his 
positions during the 1848 revolutions shows that he opposed violence and force against the government at every point (Allen, 1952: pp. 3-9).

To be clear, this view on the nature of power has its merits (see: Bernstein, 2013: pp. 78-104). It remains the task of every emancipatory political project to challenge those political imaginaries that unreflexively equate politics with force and violence. However, its particular take on the relation (or, rather, non-relation) between political change and violence is problematic. For instance, it is not very clear whether the oppositions that are established in such a view - between dialogical cooperation and mute violence, or being-with-others and the domination of others - can always be upheld. ${ }^{10}$ This is especially the case in revolutionary situations as temporal pressures and the opposition of fellow citizens work together to undermine cooperative politics (Breen, 2012: pp. 144-50). The problem with this position, however, is not that it presents a non-violent version of radical political change. What is problematic is the implicit assumption that political change and non-violent change are identical. Non-violence is no longer a strategy, but is simply inherent to the nature of the political.

We do not believe, however, that this is a tenable position. It is not possible to strictly separate politics and violence. This brings us into the realm of Balibar's third concept of politics: the politics of civility. All forms of radical politics, as he argues, face a tragic dilemma: we 'need to politically transform the existing state of things - characterized by structural and circumstantial violence - though we can renounce neither the struggle for emancipation nor resistance (interior or exterior) to the nihilism of violence' (Balibar, 2009: p. 11). There is always a risk that, in the face of oppression, a revolt or a revolution turns into destructive or selfdestructive counter-violence (p. 29). The tragic character of political action consists in the fact that it can never completely divest itself of the different forms of violence, but once this violence gets out of control (that is, turns into extreme violence or cruelty) politics is made impossible as the shared political space collapses under the weight of hostilities. Once this happens, the conditions for political action to occur disappear and - perhaps more significant for a politics of transformation -so does the possibility of a truly political conflict (Balibar, 2015b: p. 47).

This involves an important perspectival shift: instead of opposing politics to violence in general, it opposes politics to a type of violence-namely, cruelty. Cruelty is that kind of violence that can never be converted into a form of political change. Cruelty is an extreme form of violence that severs all relations - of communication as well as conflict - between opposing political groups. But political violence is not reducible to cruelty and as a consequence political violence is not to be condemned a priori. Instead what is opened up is a realm of political action in which an active choice 
has to be made between different political strategies, some of which involve violence and others of which adhere to non-violence. These are what Balibar calls strategies of civility: they intervene in the politics of emancipation and transformation in order to prevent them from slipping into anti-politics (or cruelty) (Balibar, 2015a: p. 51). In this particular respect, Balibar's thought is deeply Weberian: it is not impossible that the limited exercise of violence might prevent a far worse violence. Consequently, resistant actors need to develop a political ethic that is appropriate to this tragic nature of political action. They have to cultivate a political sensibility appropriate to a world that often is violent, meaning that they have to learn when to avoid violence, but also - if necessary - when to resort to violence (Balibar, 2009: pp. 28-9).

We argue that Commun is lacking such a perspective precisely because it (a) analytically separates the concept of political action from that of violence and (b) overemphasizes the cooperative nature of the politics of the common. ${ }^{11}$ What is missing in this account is an appraisal of the different ways in which resistance to forms of violence - for example, in the form of a confrontation between the politics of the common and the authority of state - inserts the politics of the common into a dynamic of violence that it can neither evade nor control. In the following section we will sketch this dynamic of violence between state and the politics of the common. We do this in order to show why the problem of civility is a concrete problem for the politics of the common.

\section{AS THE COMMON CONFRONTS THE STATE: THREE POSSIBLE SCENARIOS}

The politics of the common presents a challenge to state authority in many ways, but the mutual exclusivity of modern constitutionalism and the 'law of the commons'12 is probably the clearest manifestation of such a challenge (see also Part III of this volume). The modern, Western tradition of law ascribes a fundamental importance to state sovereignty, public property and private property, and is therefore fundamentally irreconcilable with the law of the common (Dardot and Laval, 2014: p. 467; Bailey and Marcucci, 2013: p. 973; Broumas, 2015: p. 14) (see also Mattei, Chapter 10 in this volume). For instance, whereas the law of the common refuses to appoint a proprietor of the common (the common is inappropriable and, thus, cannot belong to anyone), the Western tradition cannot conceive of a common without an owner (Dardot and Laval, 2014: p. 470; Broumas, 2015: p. 18). ${ }^{13}$

Should these legal orders clash at some point, different scenarios are conceivable. First, we could witness an illegalization of practices of 
commoning. States have an interest in preventing these new ways of organizing common life from stabilizing into new institutions, so they could prohibit them. They are, for instance, already doing this by tightening anti-squatting laws (Vishmidt, 2014). ${ }^{14}$ A continuation of these practices in the face of their illegalization could have the effect of reinforcing state authority. As Hans Lindahl notes, even though illegal behaviour 'breaches legal order, its qualification as illegal has a "positive" normative significance: illegality counts as the privative manifestation of legal order, hence as its reaffirmation' (Lindahl, 2013: p. 28). As long as these confrontations between commoners and the state are relatively rare and the community of citizens recognizes the illegality of the commoners' acts, the state is 'justified' if it responds to resistance with violence.

A second, contrasting scenario would see the incorporation of practices of commoning into the legal order of the state. One example is the occupation of the Teatro Valle in Rome - demanding that culture be recognized as a common good - and its subsequent legalization. Whereas the initial occupation of the Teatro was illegal, the occupants managed to get legal recognition for the occupation through the employment of a private law tool (Bailey and Marcucci, 2013: p. 399). The problem with this strategy, however, is that it only works insofar as state authority is not fundamentally threatened. Once the state notices that legal(ized) practices of commoning threaten its authority, it might impose additional legal measures. For instance, new legal demands were imposed on the Teatro Valle threatening to hinder its operation (Vishmidt, 2014; Dardot and Laval, 2014: p. 479).

A third scenario, we argue, coincides with what Dardot and Laval call the auto-institution of society: in this case practices of commoning would be so widespread and normatively pertinent that they actually challenge the distinction between legality and illegality. They would constitute what Hans Lindhal calls, a form of a-legal behaviour 'that deplete[s] the normativity of a legal order' as it reveals how this same legal order closes down on the possibility of acting in ways that 'claim a normative force of their own' (Lindahl, 2013: p. 36). For example: commoners might breach property laws, but at the same time their practices of sharing claim a normative force of their own. Accordingly, they compel us to question certain normative distinctions inherent to the regulation of property as codified in the legal order.

In the end, most revolutions end up re-enacting scenes of all three scenarios: the fragile beginnings that are in danger of being suppressed, the recurring risk of co-optation, but also the possibility of becoming a true event that - if only for a moment - upends our conceptions of what is and is not politically feasible. The challenge for commoners exists in getting from scenario one - the fragile beginnings - to scenario three - the start of 
a revolutionary transition - without succumbing to state violence. As some theorists have already noted, it is naïve to think that practices that challenge the state as a unity of power (even in cases where this challenge is not explicit) will not elicit a violent response. The fact that states are nowadays increasingly losing power due to processes of globalization and decentralization does not curb this tendency. On the contrary, in order to maintain the illusion of the unity of power they resort to visible supplements to whatever power they still have, and state violence seemingly provides such a supplement (Balibar, 2015b: pp. 38-42; Jameson, 2016: p. 4).

Another factor to take into account is that state violence - as Johanna Oksala argues - is inherent to neoliberal governmentality. As we already argued in the introduction, neoliberalism is a constructivist project - it is a project that recognizes its own artificiality. Market competition is never taken as a natural given, but is something that has to be brought into existence through 'permanent vigilance, activity and intervention' (Oksala, 2012: p. 140). State violence is one of the means through which market competition is created and secured. This explains why practices of commoning that are not co-optable are met with violence. As Oksala notes, '[t]he violent suppression of such activism in Western democratic states must be seen not only as an attempt to protect private property effective policing of the economic game - but also as an attempt to close off possibilities for opting out of it' (p. 141). In these cases violence is not merely restrictive, but also productive of subjectivity (p. 105). That is to say, state violence does not only protect private property, but also guards the boundaries of political and social reality: it establishes which ways of living are acceptable, and which ones are not. ${ }^{15}$

In this context, resistance to a state - whether it presents itself as insubordination, revolution or subversion - might initiate a cycle of violence. The political problem that this dynamic poses, forces resistant or revolutionary actors to develop strategies that would allow them to further their resistance or revolution while - at the same time - resisting the logic of the escalation of violence.

\section{THE COMMON(S) AND STRATEGIES OF CIVILITY}

In this last section, we will explore the role that violence could play in the revolutionary politics of the common. ${ }^{16}$ The problem that we should tackle, then, is that violence and democracy, which is central to the definition of the common, are generally seen to be opposites. Violence, or 'the use of considerable force or destroying force against people or things' 
(Honderich, 1980: p. 153), is deemed to be incompatible with uncoerced, egalitarian and autonomous democratic decision-making. ${ }^{17}$ This same argument would also be relevant for Dardot and Laval. Democracy, as Dardot defines it, can be characterized as 'co-participation in public affairs' and 'self-government' (see Dardot, Chapter 2 in this volume). Violence seemingly does not fit into this picture.

Nonetheless, political violence could enter the scene in roughly two kinds of situations: either, when the logic of the common is extended through the strategic or non-strategic use of violence, or, when practices of commoning have to be defended against hostile actors.

\subsection{Extending the Logic of the Common through Violence}

Regarding the first kind of situation, we would adhere to Dardot and Laval's reluctance towards the strategic use of violence in pursuit of longterm political and economic goals (for example, Dardot and Laval, 2014: pp. 84, 451). The instrumentalization of violence is not an appropriate strategy for a democratic commons revolution. For one, as Howard Caygill points out, there is a tension between 'the political control of violence, and the inherent tendency of violence to escalate beyond such control' (Caygill, 2013: p. 81). Violence is nothing like an instrument. It is part of a complex set of dynamics that cannot be controlled by its perpetrators. Although violence might help to achieve certain short-term goals, its unpredictable consequences tend to overwhelm long-term goals (Frazer and Hutchings, 2008: p. 103).

More importantly, violence is not only too unpredictable to be instrumentalized, it also has a bearing on the subjectivity of those that exercise it. The dynamics of violence, once unleashed, do not only play out in the physical realm, but also in the realm of imaginary representations. Images of enmity, destruction or conspiracy capture the subjectivity of political actors and consequently introduce forms of cruelty in what was once a political conflict (Balibar, 2015a: pp. 105-6). Of course, one could - as Georges Sorel does - celebrate violence's function as an accelerator of social divisions (Sorel, 1961 [1908]). In order to understand Sorel's perception of revolutionary violence, we have to comprehend his political voluntarism. Orthodox Marxists believe class antagonism derives automatically from an objective conflict in social reality - the conflict of interests between the proletariat and the capitalist class. Sorel, on the other hand, recognizes that this objective conflict does not translate mechanically into a subjective conflict. Class consciousness is not produced by the objective existence of classes, but has to be created politically and ideologically (CiccarielloMaher, 2017: pp. 28-33). Violence, then, plays a role in the creation and 
delimitation of class consciousness. To be clear, Sorel does not believe that violence has a purely instrumental function: it should not be put to use in order to implement utopian plans. On the contrary, Sorel despises the figure of the Jacobin: the revolutionary who claims to have uncovered a moral truth or the laws of history and intends to implement this truth through the use of force and violence (Ibid.: pp. 26, 36). Instead, violence has the function of unifying the working class, on the one hand, and the bourgeoisie, on the other. Violence polarizes and, as a result, clarifies the lines of conflict. Moreover, it provokes the state in the hope of revealing its true face as its repressive function becomes apparent. Consequently, violence neither has a strategical function, it is not put to use as a means to achieve long-term goals, nor does it necessarily have a tactical function, it is not used to break the enemy's will in a specific situation. Violence, rather, has a theatrical function: it provides the proletariat with a narrative that motivates and orientates (Finlay, 2009: p. 32).

Would this form of violence, drastically stripped of the illusion of its controllability, be more appropriate to a commons revolution? As Ernesto Laclau and Chantal Mouffe argue, Sorel's thinking provides a welcome antidote to a form of economic determinism that completely eliminates the factor of political will (Laclau and Mouffe, 2014 [1985]: pp. 30-36). In this sense, it fits nicely with Dardot and Laval's project of breaking with the determinist tendencies present in some theories of the common (see Section 1). On the other hand, however, we believe this approach to violence would be problematic for two interrelated reasons. For one, it puts the horse before the cart. Sorel was, of course, rightfully critical of revolutionaries that put violence in service of a political project. However, in turn, he made the opposite mistake of assuming that, once violence performed its polarizing function, the contours of a proletarian political project would materialize. As Elisabeth Frazer and Kimberly Hutchings argue, Sorel upholds 'an ethic of struggle in which fighting well is more important than being able definitively to articulate the substance of what you are fighting for' (Frazer and Hutchings, 2009: p. 57). This seems like a problematic stance to say the least. Although antagonism plays an important part in any revolution, the real basis of its power is its creative energy - the fact that a political experiment is taking place. While this does not mean that one has to have a political blueprint at hand, eventually a political project - the substance of what you are fighting for - should emerge from these revolutionary practices and the debates surrounding it.

A second problem, as Sorel's own discourse already shows, is that this position involves a shift from political action to acts of war (Sorel, 1961 [1908]: 115). Sorel essentially depoliticizes both violence and revolution: violence is meant to sever all political and ethical relations between the 
proletariat and the capitalist class (Laclau and Mouffe, 2014 [1985]: p. 33; Frazer and Hutchings, 2009). As Balibar points out, this is the paradox that any attempt to equate class struggle to civil war produces: on the one hand, civil war appears as the condition of possibility of politics: without it a radically new form of politics can never emerge. But on the other hand, it becomes a condition of impossibility of politics as the political space, where communication and conflict between opponents can emerge, collapses (Balibar, 2017: p. 164). Hence, also in this respect the Sorelian account of violence falls short of the politics of the common. As Dardot and Laval stress at multiple points in their argument, the politics of the common always require a self-alteration of the political actors involved. Commoners change themselves as they change the world around them. They develop certain habits, patterns of action and a form of selfunderstanding appropriate to democratic acting-in-common (Dardot and Laval, 2014: pp. 436-45). However, this also applies to violent political action. The problem then is that violence could negatively affect the actors' subjectivity. Violence, as John Kean succinctly puts it, 'kills off the potential democrat in both the violator and violated' (Kean, 2004: p. 156). A form of extreme, antagonistic violence would, eventually, form an obstacle to the universalization of the logic of the common as political relations are dissolved into absolute divisions between warring factions.

\subsection{Defending the Logic of the Common through Violence}

Whether this aversion towards political violence can be upheld in situations where democratic commons have to be defended, however, remains in question. When it comes to this matter, Dardot and Laval's position is not entirely clear. As we already noted, their main focus lies on socialist cooperative practices (associations in French) - their democratic nature, practices of sharing, the institution of rules of cooperation and their pedagogical function (Dardot and Laval, 2014: pp. 391-403, 497-505). Be that as it may, their discourse on the defence of these associations is couched in terms that suggest conflict (for example, the language of struggles or resistance (pp. 484, 501)), but do not confront the question of violence head-on. However, practices of commoning often (if not always) find themselves in situations defined by particular forms of violence they cannot simply subtract themselves from. We will thus have to find a way to navigate the paradox of civil violence, which consists in the fact that there are 'times and circumstances ... when violence functions as a basic, if highly paradoxical, precondition of the pursuit or preservation of a civil democracy' (Kean, 2004: p. 139). 
Applied to the specific subject at hand, this might mean that in order to distance themselves from the state, networks of commons will have to find ways to undermine its monopoly of violence. For instance, there may be specific cases in which political violence is warranted to the extent that it helps 'defend the spaces ... opened up for non-violent political action from the forces trying to suppress or destroy them' (Finlay, 2009: p. 37). Throughout the history of cooperative practices we can find multiple instances of this phenomenon. Take, for instance, the Paris Commune of 1871: as Martin Breaugh confirms, the living heart of the Commune were the clubs and societies that operated according to the principle of association and constituted a veritable alternative to state power (Breaugh, 2007: pp. 364-74). Still, violence was not entirely missing from this picture. While physical violence may have been rare and was seldom gratuitously employed, verbal and symbolic violence were less so. These different forms of violence and the potential threat of physical violence created an atmosphere in which opponents of the Commune where more wary of intervening (pp. 296-7). Still, we all know what happened to the Commune: it ended up being violently repressed.

This is why it is worth considering a more contemporary example, which Dardot and Laval refer to as well (Bauwens, 2016): Rojava, also known as the Democratic Federation of Northern Syria. Rojava is an autonomous region in the northern part of Syria that consists of three self-governing cantons: Afrin, Jazira and Kobani. What makes this political entity so extraordinary is the fact that it approximates - although imperfectly - what we take to be a federation of commons. It is organized according to the principles of direct democracy, democratic confederalism, economic and social life are democratized, and ecological principles are central to the organization of their society. Last, but certainly not least, it organizes society in a way that continuously defends 'itself against the emergence of centralized power and state-ness' (Üstündağ, 2016: p. 199). In other words, it consciously subverts the process of nation state formation.

This radical experiment, however, takes place in circumstances that are hostile to say the least. On the one hand, Rojava has to deal with a Turkish state, which is determined to suppress Kurdish autonomy. On the other hand, it is constantly on the defence against Islamist organizations such as al-Nuzra and ISIS seeking to extend their territory (pp. 197 and 205). This implies that Rojava is confronted with the paradox that we outlined above, having to defend their achievements against hostile forces, without abandoning their principles. The practical solution that the Rojavans developed in response is fascinating. Instead of organizing their resistance in response to the violence/non-violence dilemma, they posed the problem as a choice between the monopolization of violence, on the one hand, and 
the democratization of violence, on the other. If the choice between violence and non-violence is not an option, then the organization of a defence against reactionary violence should be democratic to its core. Nazan Üstündağ describes how this plays out in the day-to-day reality of Rojava: '[the] self-defence of women requires', she writes, 'that women and men participate equally in all formations, institutions, economies, and leadership positions'. In addition, all institutions must give women and youth the right to veto any decision affecting them so that they can defend themselves against the corruption of the men and the elderly (pp. 199-200). In other words, there are mechanisms in place that prevent the monopolization of violence in the hands of the few.

What is admirable about the Rojava case is that it proves new, democratic forms of life can be built despite the context of an armed struggle. Hence, we should not succumb to the allure of military heroism. As Michael Hardt and Toni Negri forcefully argue, the only proper way to judge the efficacy of the weapons of self-defence is to judge them 'first and foremost for how they serve the constructive struggle [of] creating and maintaining ... new forms of life' (Hardt and Negri, 2017: p. 271). Moreover, different contexts require different weapons. Strategies of guerrilla warfare are out of place in our Western, liberal democracies. In this context, violence might be more limited and geared towards protecting people from police violence or the violence of far-right movements. The main lesson that Rojava teaches, then, is that while violence might play a role in the defence of what are sometimes fragile, new forms of life, it should not overtake them. This intricate balancing act should be at the centre of a democratic revolution of the common.

\section{CONCLUSION}

In order to restate our argument, let us return to what are ultimately the stakes of the revolution of the common: proposing an alternative to a dominant neoliberal governmentality. Leaving its devastating effects to the side for a moment, what is so problematic about this neoliberal rationality is that it presents serious obstacles to resistant and revolutionary actors. Neoliberal forms of subjectification, for instance, isolate citizens from each other as competition becomes the organizing principle of society. Isolation and competition, in turn, prevent forms of solidarity from emerging. In the striking formulation of Alex Williams, we are living in a time of negative solidarity: not merely the absence of solidarity, but an active resentment towards those willing to act collectively in order to demand a form of justice. If I truly believe that better living conditions or 
better working conditions should be the result of personal achievement, then collective action can only be seen as spoiling the party. And if I am willing to endure hardship because I know that one day $I$ will succeed, then others must do so too (instead of wanting to change the rules of the game through collective action) (Williams, 2010). In this sense, Dardot and Laval's principle of the common responds to the root of the problem: if competition between isolated actors is the organizing principle of society, then learning to act in common is the first and foremost task of a revolutionary politics. Commoning is not only an alternative way of organizing economic and social life, it is also a pedagogic project that teaches people how to resist neoliberal subjectivity.

We believe this context partly explains Dardot and Laval's theoretical positions. If we have to overcome a rationality that opposes people to each other as competitors and does not have a concept of the common good, then cooperating to reach a common goal becomes a form of resistance in itself. Moreover, if we do not want to repeat the mistakes of past revolutionary movements that ended up in authoritarian regimes, we have to develop an alternative conception of power. This is why Dardot and Laval reach back to a leftist tradition of cooperative, non-authoritarian political and social thinking. We agree with Dardot and Laval that the insights of this tradition are absolutely indispensable. However, as our short genealogy of the concept of power in this tradition shows, the unintended result is that questions of revolutionary violence and force stop being posed. As a result, an alternative leftist tradition that sees politics in terms of radical antagonism and division is left to the side. ${ }^{18}$

However, resistance to our contemporary neoliberal states will eventually impose exactly these kinds of questions. History has shown that states do not take kindly to movements that challenge their authority and neoliberal states will likewise respond with violence. Resistance and revolutions unfold in situations that ask of political actors to consider different strategies of civility, some of which are violent and some of which are not. And as we maintained in the last section, while non-violence might be a valid strategy, so are certain forms of defensive violence. At times these forms of self-defence might be the only way in which a radical political experiment can be sustained.

\section{NOTES}

* The research for this paper was funded by an FWO research grant. The author would like to thank Antoon Braeckman, Nicolás Brando, Samuel Cogolati, Martin Deleixhe, Rutger Hagen, Pierre Saûvetre and Nils Vanstappen for their comments. 
1. As Wendy Brown, who coined the idea, explains: 'Neoliberalism is a constructivist project: it does not presume the ontological givenness of a thoroughgoing economic rationality for all domains of society but rather takes as its task the development, dissemination, and institutionalization of such a rationality' (Brown, 2005: pp. 40-41). These ideas essentially go back to the work of Michel Foucault (Burchell et al., 2008).

2. Since this chapter is mainly focused on the relation between practices of commoning and the state, it might give the impression that the revolution of the common should be restricted to the national level. We would like to make clear that this is definitely not the case. First, Dardot and Laval themselves emphasize that the revolution of the common will be a global and 'cosmopolitical' revolution (Dardot and Laval, 2014; also see Chapter 2 in this volume). Second, global governance is a necessary component of neoliberal governmentality. It is impossible to clearly separate neoliberal governmentality on a national level and neoliberal governmentality on the transnational and global levels. (I would like to thank Samuel Cogolati for highlighting this crucial point.) However, we do believe that there are good reasons to focus on the relation between the common and the nation state. The most important one being that this is a chapter about violence and, as of now, nation states still have a monopoly on the legitimate exercise of violence. It is possible that nation states will at some point lose this monopoly, or that this monopoly will be transformed. However, we believe that this will ultimately not affect our argument.

3. We leave the definition of 'radical political change' relatively open. The adjective 'radical' merely expresses a difference with political change that takes place within the confines of the status quo (for example, a change of government or a new law being passed).

4. This accentuation of the importance of the social revolution and a critical attitude towards a specific take on political revolutions (defined as attempts to 'seize power') is typical of most commons literature (see, for example, De Angelis, 2014).

5. The very fact that they are seen as modalities of political action, does not imply that violence and coercion are always legitimate forms of political action.

6. Another way to look at the commons literature in relation to the question of power is to work with the pairings 'power-to' and 'power-over', on the one hand, and 'potential' and 'potesta', on the other (Van de Sande, 2017). However, this leads to slightly different stakes: here, the question of violence gives way to the question of the ontological relation between the common and the social and political structures it struggles against. The question then becomes: are commons internal to these structures or are they, or do they become, external to them?

7. Dardot and Laval are influenced by Arendt's work on the council system, but disapprove of her strict separation between the political and the social. For Arendt the council system is a purely political innovation, whereas for Dardot and Laval its novelty consists in the merging of the political and the social (Dardot and Laval, 2014: p. 401).

8. We do have to add that Dardot and Laval appropriate these influences in a critical way. In the case of Elinor Ostrom they build on her institutional analysis, but take her to task for restricting the logic of the common to a specific place in society. That is to say, they criticize her because Ostrom - as an economic pluralist - thinks that the commons could live peacefully beside the state and the market (as opposed to becoming a rival logic) (Dardot and Laval, 2014: pp. 155-7). In the case of Proudhon, they point out that he insists too much on the social and apolitical logic of worker's self-organization. In contrast, Dardot and Laval contend that these forms of self-organization are political through and through (something which the later Proudhon came to accept as well) (p. 382).

9. There exists, for instance, a literature exploring the relation between non-violence and authoritarianism. A strict adherence to non-violence can lead to the emergence of hierarchies where some come to occupy a place of moral authority that allows them to police the behaviour of others (Frazer, 2016: pp. 5-6).

10. There is, as Martin Deleixhe has argued, also an internal aspect to this assertion: that is, underlining the cooperative aspect of the politics of the common also distracts from 
the internal conflicts that either already exist or may arise. As a result, different forms of domination in commons (for example, women bearing the brunt of the labour in commons) disappear from view (Deleixhe, 2018).

11. There is a clear tendency in the literature on the commons to emphasize the need for a new paradigm of legality. The assumption being that there are some elements in the tradition of modern constitutionalism (for example, the importance of property rights, the legal enshrinement of a particular form of representative democracy and so on) that conflict with the principles that inhere in practices of commoning. That is why most of these thinkers develop some version of an alternative law of or for the common(s).

12. However, this does not mean that we should reduce this conflict to its strictly legal terms. A legal order is always more than a set of rules: it entails specific forms of subjectivity and norms that shape the practices of those subject to them.

13. It should be noted that not all forms of squatting are automatically acts of commoning. Squatting becomes an act of commoning when the right of use - in the form of a right to have a roof over one's head - is opposed to the right to property. Another important factor is that the squatters/commoners autonomously and democratically develop rules that regulate this right of usage.

14. And this is still leaving out the factor of race, a question about which Dardot and Laval - focused on a more traditional, white labouring class - have little to say. Should the logic of the common become universal, it will have to develop a more expansive concept of the working class. Hence, it will have to include a population that, often due to the factor of race, lives on the borders between the proletarian condition and that of the lumpenproletariat. However, this surplus population, as became evident in the twentieth- and twenty-first-century race riots, is more intensely caught up in a relation with state violence (see: Clover, 2016: pp. 130-92). A proper consideration of the relation between the common(s) and race, however, would take more space that this chapter can offer. For two important takes on the subject see: Harney and Moten, 2013; and Mezzadra and Neilson, 2013: pp. 277-312.

15. Of course, as we argued above, the set of strategies of civility also includes non-violent strategies. However, within the limits of this chapter it is not possible to cover both violent and non-violent strategies in depth. Since non-violent strategies have been at the centre of the commons literature, it seemed more appropriate to shed some light on a topic that is less written about in relation to the common(s).

16. Even, as John Medearis notes, in its more radical and oppositional forms (Medearis, 2015: p.148).

17. This is not to suggest that there can be no overlap between these two traditions. The most interesting political positions are the ones that balance the two traditions.

\section{REFERENCES}

Allen, M. B. (1952) P.J. Proudhon in the Revolution of 1848. The Journal of Modern History, 24 (1), 1-14.

Arendt, H. (1969) On Violence. San Diego, Harcourt.

Arendt, H. (2016 [1963]) On Revolution. London, Faber and Faber.

Bailey, S. and Marcucci, M. E. (2013) Legalizing the Occupation: The Teatro Valle as a Cultural Commons. The South Atlantic Quarterly, 112 (2), 396-405.

Balibar, É. (2002) Politics and the Other Scene. London, Verso Books.

Balibar, É. (2009) Violence and Civility: On the Limits of Political Anthropology. Differences: A Journal of Feminist Cultural Studies, 20 (2/3), 9-35.

Balibar, É. (2015a) Violence and Civility: On the Limits of Political Philosophy. New York, Columbia University Press. 
Balibar, É. (2015b) Violence, politique, civilité. In: Caloz-Tschopp, Marie-Claire (ed.) Violence, civilité, révolution. Paris, La Dispute, pp. 15-50.

Balibar, É. (2017 [1993]) The Philosophy of Marx. London, Verso Books.

Bauwens, M. (2015) Interview with Pierre Dardot and Christian Laval on the Politics of the Common. P2P Foundation. Available from: https://blog.p2pfound ation.net/interview-with-pierre-dardot-and-christian-laval-on-the-politics-ofthe-common/2015/07/24 (accessed 11 July 2018).

Bernstein, R. J. (2013) Violence: Thinking without Banisters. London, Polity.

Breaugh, M. (2007) L'expérience plébéienne: Une histoire discontinue de la liberté politique. Paris, Editions Payot et Rivages.

Breen, K. (2012) Under Weber's Shadow: Modernity, Subjectivity and Politics in Habermas, Arendt and Macintyre. Surrey, Ashgate.

Broumas, A. (2015) Movements, Constitutability, Commons: Towards a Ius Communis. Law and Critique, 26, 11-26.

Brown, W. (2005) Edgework: Critical Essays on Knowledge and Politics. Princeton, Princeton University Press.

Burchell, G., Davidson, A. and Foucault, M. (2008) The Birth of Biopolitics: Lectures at the Collège de France 1978-1979. London, Palgrave Macmillan.

Caygill, H. (2013) On Resistance: A Philosophy of Defiance. London, Bloomsbury.

Ciccariello-Maher, G. (2017) Decolonizing Dialectics. Durham, Duke University Press.

Clover, J. (2016) Riot. Strike. Riot. London, Verso Books.

Dardot, P. and Laval, C. (2009) La nouvel raison du monde: Essai sur la société néolibérale. Paris, La Découverte.

Dardot, P. and Laval, C. (2014) Commun: Essai sur la révolution au XXIe siècle. Paris, La Découverte.

Dardot, P., Laval, C. and El Mouhoub, M. (2007) Sauver Marx? Empire, multitude, travail immatériel. Paris, La Découverte.

De Angelis, M. (2014) Social Revolution and the Commons. South Atlantic Quarterly, Spring, 299-311.

Deleixhe, M. (2018) Conflicts in (the) Common(s)? Radical Democracy and the Governance of the Commons. Thesis Eleven, 144 (1), 59-79.

Finlay, C. J. (2009) Hannah Arendt's Critique of Violence. Thesis Eleven, May, 26-45.

Frazer, E. (2014) Power and Violence. In: Hayden, P. (ed.) Hannah Arendt: Key Concepts. Durham, Acumen, pp. 155-66.

Frazer, E. (2016) The Diversity of Tactics: Anarchism and Political Power. European Journal of Political Theory, Advance Publication.

Frazer, E. and Hutchings, K. (2008) On Politics and Violence: Arendt Contra Fanon. Contemporary Political Theory, 7, 90-108.

Frazer, E. and Hutchings, K. (2009) Politics, Violence and Revolutionary Virtue: Reflections on Locke and Sorel. Thesis Eleven, May, 46-63.

Geuss, R. (2006) Dialectics and the Revolutionary Impulse. In: Rush, F. (ed.) The Cambridge Companion to Critical Theory. Cambridge, Cambridge University Press, pp. 103-38.

Hardt, M. and Negri, T. (2017) Assembly. Oxford, Oxford University Press.

Harney, S. and Moten, F. (2013) The Undercommons: Fugitive Planning and Black Study. New York, Minor Compositions.

Honderich, T. (1980) Violence for Equality: Inquiries in Political Philosophy. Harmondsworth, Penguin Books. 
Jameson, F. (2016) An American Utopia. In: Žižek, S. (ed.) An American Utopia: Dual Power and the Universal Army. London, Verso Books, pp. 1-96.

Kean, J. (2004) Violence and Democracy. Cambridge, Cambridge University Press.

Laclau, E. and Mouffe, C. (2014 [1985]) Hegemony and Socialist Strategy: Towards a Radical Democratic Politics. 2nd edn, London, Verso Books.

Lindahl, H. (2013) Fault Lines of Globalization: Legal Order and the Politics of A-legality. Oxford, Oxford University Press.

Medearis, J. (2015) Why Democracy is Oppositional. Cambridge, Harvard University Press.

Mezzadra, S. and Neilson, B. (2013) Border as Method, Or the Multiplication of Labor. London, Duke University Press.

Oksala, J. (2012) Foucault, Politics and Violence. Evanston, Northwestern University Press.

Ostrom, E. (2000) Collective Action and the Evolution of Social Norms. Journal of Economic Perspectives, 14 (3), 137-58.

Ostrom, E., Walker, J. and Gardner, R. (1992) Covenants With and Without a Sword: Self-governance is Possible. American Political Science Review, 86 (2), 404-17.

Penta, L. (1996) Hannah Arendt: On Power. The Journal of Speculative Philosophy, $\mathbf{X}(3), 210-29$.

Ross, K. (2015) Communal Luxury: The Political Imaginary of the Paris Commune. London, Verso Books.

Saar, M. (2010) Power and Critique. Journal of Power, 3 (1), 7-20.

Solari, S. (2012) The 'Practical Reason' of Reformers: Proudhon vs. Institutionalism. Journal of Economic Issues, 46 (1), 227-40.

Sorel, G. (1961 [1908]) Reflections on Violence. Toronto, Collier Books.

Üstündağ, N. (2016) Self-defense as a Revolutionary Practice in Rojava, or How to Unmake the State. The South Atlantic Quarterly, 115 (1), 197-210.

Van de Sande, M. (2017) The Prefigurative Power of the Commons. In: Ruivenkamp, G. and Hilton, A. (eds) Perspectives on Commoning: Autonomist Principles and Practices. London, Zed Books, pp. 25-63.

Vishmidt, M. (2014) All Shall Be Unicorns: About Commons, Aesthetics, and Time. Open. [Online] Available from: www.onlineopen.org/download.php?id=128 (accessed 12 June 2016).

Weber, M. (1978) Economy and Society, Vol. I. Oakland, University of California Press.

Williams, A. (2010) On Negative Solidarity and Post-Fordist Plasticity. Splintering Bone Ashes. [Online] Available from: http://splinteringboneashes.blogspot. be/2010/01/negative-solidarity-and-post-fordist.html (accessed 30 October 2017). 